Öneri, C.1, S.3

Haziran, 1995, ss.111-118

\title{
THE IMPLEMENTATION OF TOTAL QUALITY MANAGEMENT: A CASE STUDY
}

\author{
Dr. Mustafa KÖSEOĞLU-Dr. Hilmi ZENGİN ${ }^{*}$
}

\begin{abstract}
This study consists of three manufacturing firms operating in Turkey. To obtain information about Total Quality Management. (TQM) practice, two multinational and one national manufacturing firms of approximately the same size (in terms of employees) in different industries were selected for the study. A structured interview was conducted to examine the implementation of TQM in the selected organisations. This study reports the findings from three organisations which have introduced TQM
\end{abstract}

\section{Introduction}

In the past couple of years there has been increased interest shown by business and govemments in the concept of Total Quality Management (TQM) in the Turkish manufacturing industry. The government provides incentives for organisations to introduce (TQM) and business has recently established the Turkish Quality Society (KalDer). The purpose of the Turkish Quality Society (TQS) is to create a framework which can explore, exchange, work together and accelerate the process of implementing TQM in Turkey. Turkey is a developing country and its economic growth is to large extent dependent on foreign investments in the manufacturing sectors. Companies in Turkey discovered TQM in the late $1980 \mathrm{~s}$. As a result implementation has only taken place recently. A further increase in implementation is to be expected over the next few years.

In recent years, some extensive sample surveys have investigated the state of TQM implementation and development throughout Westem countries: such as Lascelles \& Dale (1989, 1990); Blauw \& During (1990) and Newall \& Dale (1991) but there has to date been nothing similar in Turkey. Based on the current literature, there are very large gaps between the body of knowledge between developed and developing countries. It has been found that there is a complete lack of theoretical and empirical study available in this field. Most of the studies of quality management practice have been in developed countries. The intention of this study is to begin the process of filling these gaps in the literature. This study involves three companies (Swedish, American and Turkish) operating in Turkey. The main objective are to determine their emphasis on TQM practices and factors that influence implementation of TQM.

\section{The concept of TQM}

During the last decade the concept of quality has evolved from the final inspection to production control and later on Total Quality Management. TQM is a term that is in common use today. Like its predecessor "quality", it is still rather an abstract term and many people find it difficult to quantify the meaning of TQM. There are a number of leading pioneers and proponents of the TQM idea, notably Crosby (1979), Feigenbaum (1983), Deming (1986), and Juran \& Gryna (1986). The TQM approaches emphasises the need for change in the organisation culture.

The culture change required is not possible without different processes operations. The gurus stress that it can take several years to obtain results. Oakland (1989) states that TQM is an approach to improving the effectiveness and flexibility of business as a whole and is a method of ridding people's lives of wasted effort by involving everyone in the process of improvement. Dale (1989) suggests that team work and cost effective improvement activities are the key to the successful implementation of TQM which must be senior management driven. İshikawa (1985) uses the term "company-wide quality control".

\footnotetext{
KTU, Faculty of Economics and Administrative Sciences, Öğretim Görevlileri, Trabzon
} 
Most of the contributors to the literature such as Kanji (1990), Lammermeyr (1991) agree that TQM is the way of life for an organisation committed to customer satisfaction through continuous improvement and the human factor play a significant role in the implementation process of TQM. In short, TQM demands a clear focus on the customer (internal and external) and total commitment throughout the organisation. It means defining the quality in customer terms, it means making people responsible for dilality it means manaopiment commitment to vuppustise diat swpviswivility, and it means a continuum for quality improvement.

\section{Research Methodology and the selection of companies for study}

The research design consisted of a field study of manufacturing firms operating in Turkey. To obtain hard data about quality management practices, it was necessary to include different types of manufacturing organisations in terms of size, industry and market. Industries which comprised the population for this study were textile, electrical and electronics, metal, automobiles, engineering, chemical and related products.

Two different methods were used to collect data: survey questionnaire and structured interviews in selected organisations. The survey questionnaire was developed to provide a baseline for quality management practices of Turkish manufacturing firms. A total of 250 questionnaire were distributed to companies, 56 were returned the response rate was 22.4 percent Prior to the mail survey, a pilot study was conducted with some manufacturing firms and institutions to verify that the questions were clearly understood and that responses would be consistent the purpose of the study. After the mail survey, the authors undertook limited trips to examine the implementation of TQM techniques and concepts in Turkish manufacturing firms. Two multi-national (Swedish and American) and one national (Turkish) manufacturing firms of approximately the same size (in terms of number of employees) in different industries were selected for the study. These three companies were selected for the study from an earlier questionnaire survey on the extent of the TQM practices.

The data were obtained from manufacturing firms which have an experience of implementation of TQM concept and techniques: The proforma was devised to ensure that the same questions were asked at each interview. The section of the proforma comprised the following.

* Quality system

${ }^{*}$ Knowledge and understanding of TQM

* Training and motivation

* Communication

* Statistical methods

* Cost of quality

* Quality performance measurements

* Barriers to implementation of TQM

Each typical visit lasted an average of four days included interviews with managers in quality, manufacturing, engineering. purchasing as well as several hours spent working the factory floor. Questions concerned the areas as indicated above. Published materials on each organisation's quality management program and other selected documents such as annual reports and company profiles were also used. During the interview the questionnaire which had been previously completed was discussed. Answers were amplified and additional information both verbal and written was also supplied to the interviewer. The interviews gave a good opportunity to hear directly managers' opinions and views on TQM techniques and concepts.

\section{Company profile}

\section{Company A}

The company A is in chemical manufacturing industry and is a part of a Swedish-owned group. It employs 765 people. The management structure of the company was examined, with particular reference to the way in which the quality function is accommodated. Overall, the company has a board of 
management as well as board of directors. The board of management comprises four managing directors, one of whom is the chief executive, while the other three are responsible for finance, technical, and sales respectively. The entire management of the company reports to the board of management through a group of senior managers who are designated directors of product planning, home sales, intemational marketing, supply of materials, production, finance, communication, and product development.

It was noted that while quality assurance work permeated virtually the whole of the company's operations (more deeply in some branches than in others). It was also given a separate identity and not simply subsumed under other functions. There were staff designated as quality managers, quality engineers and quality technicians, all responsibility to a central quality manager reporting directly to the board of management. Within the product development project group structure the quality staff were given attachments in the specific areas of production, and marketing as well as an important coordinating role between incoming raw material inspection and the quality of the finished product. The quality staff have dual responsibilities to the central quality manager on the professional level, but also to the manager of the functional area in which they are operating on day to day matters. Moreover, it was noted that the quality function was of particular service to the project manager had on occasions been assigned to quality staff. From all the evidence gathered during this visit it is clear that quality assurance is well established as a strong technical function, and it is closely integrated with the management structure at a high level in the company.

\section{Company B}

The company $\mathrm{B}$ is in electrical manufacturing industry and is part of a corporate American-owned group, employs 860 people and manufactures consurner durable equipment in Turkey. The products are mainly for domestic consumption (85\%) and the rest are exported. The writers had the opportunity to examine the quality system documentation quite closely, and a number of points emerged. First of all, it was clear that the company was taking a very positive line in defining and developing an effective policy. Secondly, it was apparent that production, development, and management were not placed in exclusive isolated cells. The list of production related quality procedures showed that quality control activities were not limited to the production line but extended forward into the market area and backward into the area of supplies.

The "writers were shomn a produst

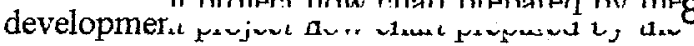
quality department in which the total project was broken down into 13 stages, and the quality. function had an involvement in 8 of them. At the operating level within the production groups the quality procedures are written in great detail. These detailed procedures are issued in quality manuals to each of the departments having an influence on the quality of the company's product. The authors were shown an internal document setting out the terms of reference of the production manager. His performance is measured in terms of relative quality costs and the market reaction to the quality of the product. His responsibilities embrace a wide range of duties including collaboration with the quality function, the preparation and issue of specifications and directives for the inspection of raw materials, the control of the manufacturing processes and the inspection and testing of the finished products. He also has to monitor the quality trend and quality costs in order to maintain the quality level and to reduce the total quality costs.

\section{Company $\mathrm{C}$}

The company $\mathrm{C}$ is a Turkish company and is concemed with the automotive industry and employs 715 people. In this company, the quality contrsl manager reports directly to the top management and works closely with the managers of engineering, manufacturing, sales and marketing to define the company quality objectives. He is also responsible for developing and implementing a product assurance system which ensures that the company's product satisfy the quality expectations of the customers, and he enjoys a high degree of independence in the execution of his duties. That is not to say that the responsibility of the various other departments for quality has been diminished in any way. It is clearly written in the terms of the reference of quality department 
that its role is to support, rather than supplant, the assurance of quality by the departments of engineering, of mamufacture, and sales.

The authors were provided with a copy of quality manual of the company. This was prepared in 1980 by the quality control manager and issued under the joint approval of the technical director and commercial director. It contains a general description of the quality assurance system and an index of the standard product assurance procedures described in detailed. The manual is intended primarily for internal use to define the quality and reliability program, but it is also used in extemal relations with customers and vendors as a reference on standards of quality. In this company, there was more emphasis on the technical aspects of quality, such as performance, reliability, safety and environmental considerations. There was less dependence on highly developed management systems and a philosophy that quality is everyone's responsibility.

\section{Emphasis towards TQM}

Interviews with employees of the three firms suggested that their senior management placed strong emphasis on the implementation of TQM. All three firms stressed that they practice a participative management philosophy and all employees are being encouraged to participate in quality control activities. All three firms organized in house quality control courses at regular intervals and also sent their employees to attend courses at their parent companies and outside institutions. The interviews showed that middle management encouragement for the implementation of TQM is not enough in their firms because they did not recognize the benefits of TQM. However, when asked whether they have succeeded in implementing TQM practices in their firms, the Swedish and Turkish firms cited difficulties and perceived that they have failed. In contrast, the American firm perceived that they were very successful. A general conclusion may be drawn that although companies put strong emphasis on TQM implementation the results are different. The next section examines main findings.

\section{Findings}

\section{Quality system}

Organisations accept that there is a need for quality management system as a foundation on which to build TQM. It is recommended that the International Standard on quality systems provides the correct framework for the build up of Total Quality Management and the objective to reach certification by a given date provides the necessary drive on all the management levels. It is also suggested that it is up to the top management to fill this system with life and action. In all cases, companies are willing to accept that ISO 9000 alone is an adequate system to meet their perceived needs. This involves setting policy, developing quality manuals, a quality information recording and analysis system, quality plans etc.

\section{Recommendation}

It is recommended that organisa-tions accept that there is a need for a quality management system as a foundation on which to build TQM. It is also recommended that the basic quality management system can be enhanced by the integration of process capability studies and subsequent monitoring of process using SPC.

\section{Knowledge and understanding}

Managers have limited access to information about TQM compared to managers in more developed countries. There are fewer joumals and books readily available in libraries, and fewer courses available at universities and other institutions of higher education. Most importantly, there are only a small number of companies attempting to implement TQM, resulting in limited opportinities for managers to discuss common problems.

Interviewees had heard of TQM from a variety of sources such as reading articles, attending seminars, visiting a company that applies TQM and the most important information is provided by the Quality Society (Kal-Der) that was established in 1990. One company studied is member of this society. Although managers are aware of the term of $\mathrm{TQM}$, there is a great divergence of understanding of concepts of TQM. To some 
managers, it is just Total Quality- to other managers it is a combination of human research development, quality improvements, quality circles, identifi-cation of customer needs or any combination of these and other programmes.

\section{Recommendation}

Although there is much literature available and accessible on TQM in the form of books written by respected authors, there is a little reason why organisations in general should not be fully conversant with the concepts and requirements of TQM. There is clear requirement for educational institutions to develop short, medium and long term strategies to educate the population in TQM. In the short and inedium term, education institutions have a responsi-bility to publicize the objectives and benefits of TQM to industry at large. They should design appropriate courses for their customers and implement TQM in their own establishments. In the long term, the TQM education process should start, as a minimum, at secondary school level and continue through higher education. İn addition, post-experience courses will continue to have a role to play. AII of this may be summed up in the expression, education for "quality of life".

\section{Training}

With the exception of quality staff, first line supervisors and shop floor employees, personnel in one company appears to have received formal management training. In companies with a traditional detection approach to quality, staff from functions such as personnel, marketing, production are often perceived as having little influence on a company's product and service quality. The role of quality function appears to be contingent on the Board of Directors' appreciation and understanding of quality management. It was found that in companies where directors are reported as having received formal quality skills training.

Only company $B$ has an induction course for all new employees stating and explaining the company's quality policy. Internal and external training courses are attended by all quality and inspection personnel allowing them to remain abreast of changes. The majority of training is being conducted by extemal sources, the main reasons for this being that expertise has lack of experience and knowledge on the subject. They believe that consultants play an important role in assisting companies who introduce TQM programs. The consultant's role varies from being a catalyst for stimulating awareness in building understanding of the TQM process, conducting training for specialized areas such as statistical techniques and other tools of TQM. Two companies claimed that all levels in the organisation are being trained.

In company $\mathrm{A}$, according to middle and first line managers, there are two obstacles to be overcome in order to implement TQM techniques and philosophy in their operations. The first is the lack of top management understanding and support. The second is resistance from workers to the new philosophy. Top management is reluctant to invest in educating workers so that they become familiar with new system and is worried about decreasing quality resulting from the changes. Employee resist the new system for many reasons. Such as significant changes create a threatening sense of imbalance in the work place and many members of the organisation desire to maintain safe, secure and predictable status. Without adequate introductory or remedial training an otherwise positive change maybe perceived in a negative light.

\section{Recommendation}

Management need to know what constitutes the subject of TQM. Organisations need to plan a strategy for training as part of the overall plan for improving the business, starting at the top of the organisation and cascading down. Management need to know where and how to obtain training.

\section{Communication}

The style of communication relating to quality is mostly formal, in writing and communicated on a regular basis. If one department which requires some information from another department cannot get it unless the request comes through a formal channel, then this cultural barrier creates an atmosphere of mistrust. In company $A$, the performance of individuals is checked by inspection. Wages, bonuses and other incentives are given on the 
basis of production quota, but not on the basis of innovation, improvement and detication.

It is found that the provision of improved feedback mechanism was appreciated by staff however the level of feedback was still regarded as generally low. This suggests that managers need skills to help them solicit feedback from their subordinates. The availability of resources was cited as a limiting factor in the variety of media used for communication.

\section{Recommendation}

Good communication is fundamental to the success of any TQM programe. Shared information usually leads to greater understanding of a problem and therefore a higher chance of buy-in to solutions or changes. The other side of communication is listening. The way to total quality is built on listening both to your customers and to every person in the company who may have ideas of how to make improvements.

\section{Statistical Methods}

The management strives to achieve quality by full inspection of critical components and finished products. This increases the cost of manufacturing. The increased costs have been compensated by introducing SPC techniques and its benefits. There is a lack of appreciation by middle and first line management, and bad labor relations caused problems in their adoption. Management have had to learn to accept involvement from shop floor employees on day to day problems. While the employees have had to accept long term goals, such as job security and job involvement rather than the more obvious short term goals of wage increases. Comnitment by both management and employees is vital for the successful implementation of TQM in this firm (C).

The results showed that the organisations introducing/implementing TQM were already using some statistical techniques and had plans to increase the use of statistical techniques in the future. However, the results also indicate that the use of techniques such as SPC, experimental design, quality costing within each organisation is patchy. This appears to have resulted from an unclear definition of the scope of the individual projects to introduce and establish that techniques.

\section{Recommendation}

Statistical methods should be used in every department of every organisation as a means of identifying and preventing common causes and removing the assignable causes of variation in all process

\section{Cost of quality}

It was found that the organisations attached little importance to activities such as quality cost and vendor rating. None of them appeared to reflect the true total cost of failure in terms of failure, prevention and appraisal. Organisations collect data on quality costs and just one of them (company B) make use of these data in decision making relating to future quality improvement. Furthermore ${ }_{f}$ the interviews carried out by the authors indicated that senior management is still unaware of the importance of quality cost collection and analysis.

\section{Recommendation}

Careful thought needs to be given to initiate costing activities in the form of failure, prevention and appraisal costs. It is believed that realistic methods should be used by every organisation to identify, record and calculate the true of quality in the forms mentioned above. The source of failure identified should lead to effective investment to prevent their recurrence and will result in increased profit.

\section{Quality performance measurement}

With the exception of quality managers, there is a general lack of management awareness of performance indicators, whether they be financially based or not. While managers are unaware, they will not be pursuing the use of appropriate measures of performance. Companies use different indicators to measure the quality management performance such as defect level, customer complaints, scrap/rework costs, market share and sales turnover. 


\section{Recommendation}

Although capability indices are valuable in comparing one process with another, the best and more understandable measure of quality is cost. Management training and education need to know recognize the importance of performance measurement.

\section{Barriers to implementation of TQM}

Most of the respondents believed that management attitude ${ }_{S}$ were a major facior which needed to be resolved. This was in the form of lack of awareness, understanding and commitment to the philosophies of TQM at all management levels. The majority of respondents perceived that the major barrier was related to the cultural changes that would be necessary at all levels within the organisation. Several respondents expressed concem over the amount of training, the resources required to do the training and time-scale which this could necessarily involve.

According to respondents, the implementation of TQM systems encounters several problems, as does any new program, such as cultural change, management behavior, measuring results, and poor communication are serious problems encountered by companies as they introduce and implement TQM.

\section{Recommendation}

Barriers can only be remedied by the education of a senior management to ensure that they appreciate that the investment in the training to follow the route to TQM will generate significant improvement to the bottom line.

\section{Conclusion and lessons learned}

It has been observed that different companies have different views and understanding towards TQM. The study suggested that in many cases companies used elements of TQM such as documented quality management policy, product planning, market research, SPC, quality costing, quality circles etc. The concept of joint responsibility between departments towards quality is not very common. It is also observed that the documented plans and procedures are too elaborate in some companies but in practice entirely different noms are followed without modification of the documented plan.

All companies recognize the importance of attitudinal change among their people in order to sustain TQM. This research shows that each organisation has adopted a different approach to the structure and implementation of their programs. Only one company has adopted a complete package offered by a parent company.

Experience has shown that in most companies considerable positive effort is necessary in order to succeed in introducing this new culture. It can only be achieved if there is the commitment to this change from the highest managerial levels of the company. Unfortunately, there are no 'quick fixes' as far as people development is concerned, it is slow but a rewarding one in the long run. The key to implementing this change is first of all in the mind. Companies will have to recognize that in the face of global competition and new standards of manufacturing efficiency, the factory must be exploited as an important source of competitive advantage. This requires engaging the full creativity of all employees and involving continuous improvement of every aspect of a company's activities.

It must be stressed that the organisations which are included in this study have not yet entered the review, reinforcement and restart phase beyond the implementation of TQM. A follow up study in 2-3 years time may yield interesting results. 
Mustafa KÖSEOĞLU-Hilmi ZENGIN

\section{REFERENCES}

BLAUW, J. N. \& DURING, W., "Adoption of an organisational innovation: Total quality control in industrial firms". INT. J. PROD. RES., Vol.: 28, No: 10, 1990.

CROSBY, P. B., "Quality is Free". New-York, McGraw-Hill, 1979.

DALE, B. G. \& ASHER, J. M., "Total quality control: The lessons european executives can learn from Japanese companies". E. M. J., 7(4), 1989.

DEMING, W. E., "Out of crisis". Cambridge University Press, 1986.

FEIGENBAUM, A. V., "Total quality control". 3rd. Edition, McGraw-Hill, New York, 1983.

ISHIKAWA, K., "What is the total quality control? The Japanese way". Prentice Hall, Englewood Cliffs, USA, 1985

JURAN, J. M. \& GRYNA, F. M., "Quality planning and analysis". McGraw - Hill Book Company, New York, 1986.

KANJİ, G. K., "Total quality management: Myth or Miracle". Total Quality Management, Vol. 1, No: 2 , 1991.

LASCELLES, D. M. \& DALE, B. G., "Quality improvement:what is the motivation". Journal of Engineering Manufacturing- Part B, Vol.: 203, 1989.

LASCELLES, D. M. \& DALE, B. G., "Quality management: The chief executives perception and role". EMJ, Vol: 8 , No: $1,1990$.

LAMMERMEYR, H. U., "Human relationships- The key to total quality management". Total Quality Management, Vol. No: 2, 1991.

NEWALL, D. \& DALE, B. G., "The introduction and development of a quality improvement process: a study". INT. J. PROD. RES., Vol.: 29, No: 9, 1991. 